\title{
洪水減水期における 水みちの形成 MECHANISMS OF CHANNEL FORMATION ON BARS AT RECESSION PERIOD OF HYDROGRAPH
}

\author{
益本 孝彦 $^{1} \cdot$ 渡邊 康玄 ${ }^{2}$ \\ Takahiko MASUMOTO, Yasuharu WATANABE \\ 1 正会員 株式会社竹中土木 東京本店 (广 136-8570 東京都江東区新砂一丁目 1 番 1 号) \\ 2 正会員 北見工業大学教授工学部 社会環境工学科 ( $\bar{T} 090-8507$ 北海道北見市公園町 165 番地)
}

\begin{abstract}
Formation of bars indicates meandering of flow and deposition or erosion in river bed. It is necessary for river improvement and water utilization to clarify this phenomenon. Therefore many researches have been conducted on bar formation. In our previous study, it was found that the channel formation process was influenced by the form of hydrograph and duration of discharge recession period.

The purpose of this study is to determine the influence given to channel formation by difference of discharge recession pattern in detail. Experiment conditions are case of constancy and variation in discharge recession speed.

It is found that the channel formation process is strongly influenced by gradient of hydrograph at discharge recession period. That is, the relationship both discharge and gradient of hydrograph(discharge recession speed) is important for the channel formation process. channel width is able to estimated by the stable channel width theory proposed by Ikeda. In addition, it is found that the active.
\end{abstract}

Key Words: $\quad$ bars,channel formation,river width,hydraulic experiment,recession period of hydrograph

\section{1.はじめに}

砂州の形成は, 流水の蛇行や砂州前縁に形成される洗 掘あるいは対岸の堆積を意味することから, 治水や利水 のため, 光の挙動を解明することが不可欠であった. こ のことから,砂州の形成および発達過程に関して過去か ら数多くの研究が行われてきている.これらの成果の一 部は, 土木学会水理委員会「洪水流の三次元流況と流路 形態に関する研究」1) に取りまとめられている.

しかし, これらの研究は, 砂州の平衡状態を中心に扱っ ており,流れが大きく変化する実際の河川への適用はあ る程度限定的なものとなっていた. 近年, 数值計算技術 の発達によって,より複雑な場での砂州の挙動を明らか にするため, 数值計算モデルの開発が行われてきた ${ }^{2)}$. 光 の結果, 実際の河川における砂州の挙動についての再現 や予測が可能となり,河道計画に利用されるようになっ てきている.さらに,生物等にとっての河川環境における 砂州の重要性も認識され, 砂州によって形成される瀬・ 淵構造に関する研究 ${ }^{3)}$ も進められてきている. 平水時に 流水が存在する水みちに関しては, 上流からの土砂供給 の視点では三輪ら ${ }^{4)}$ が, 砂州と平水時流量との関係は寺 本ら ${ }^{5)}$ が, また砂州の形状変化の観点では渡邊ら ${ }^{6)}$ が 実験, 理論解析及び数値計算等で検討を行ってきている.

しかしながら, 洪水時において水理量の時間変化に伴 う砂州の形状変化や砂州と平水時に形成される水みち

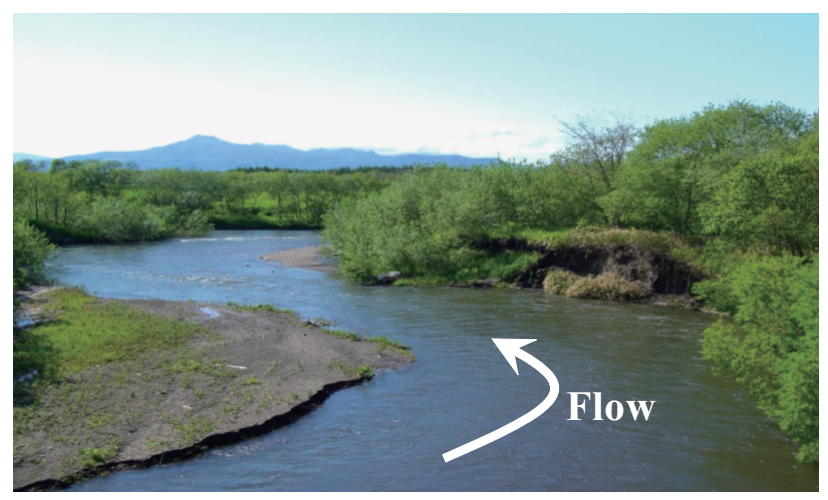

図-1 標津川の固定砂州と河道 (平成 20 年 6 月)

との関係,さらには氾濫源と河道との関係は,未だ十分に 解明されていない. 図-1 は, 標津川の河道に存在する砂 州の状況を示したものである. 洪水時に形成された砂州 に水みちが規定され, 水みちが大きく蛇行している樣子 がわかる. 洪水減水期における流量の時間的変化を伴っ た水理実験は, 工藤ら ${ }^{7)}$ が減水期間が長いほど水みちが 形成されやすいことを, 益本ら ${ }^{8)}$ が減水期のハイドロ形 状 (凹型, 凸型) の違いによる水みち形成機構の違いがあ ることを示し, 流量と川幅との関係が重要であると指摘 している.一方で, 減水期間内における流量の減水方法 や洪水時の流量から平水時の流量への変遷過程におい て水みち形成に与える影響については未だ十分に明ら 
かになっておらず, 近年多発しているゲリラ豪雨による 急激な水位上昇に伴う砂州上に取り残されるといった 被害を防ぐためにも早期の解明が望まれる. 本研究で は, 洪水時の減水期間内での流量の減水方法や減水速度 に着目し, 洪水時に形成される砂州と平水時に存在する 水みちとの因果関係について新たに追加実験を行い, 明 らかにしようとするものである.

\section{2. ハイドロ形状の設定}

既往の水理実験 ${ }^{8)}$ では, 実際の洪水減水期のハイドロ をモデルに, 減水期前半の凸型ハイドロと減水期後半の 凹型ハイドロで, 水みち形成に与える影響を調べるため, 減水期間を 20 分と固定し, 凸型ハイドロと凹型ハイド ロで, 洪水減水期に形成される水みち形成メカニズムを 解明した. 結果的に, 両者ともに水みちが形成されたが, 形成機構に差異があった. また目視の観察において, 減 水期後半に水みちが活発に形成される流量が存在する ことが明らかになっている.さらにより詳細な水みち形 成機構を把握するため, 減水期間を 2 倍の 40 分に設定 して, 上述のハイドロ形状で実験を行ったところ, 流量 がおよ光 $190\left(\mathrm{~cm}^{3} / \mathrm{s}\right)$ の時に流水幅が縮小変化し水みち 形成が活発に起こっていることが明らかになった.つま り, 流水幅が縮小変化し, 掃流力が増大する際の流量が 水みち形成に寄与していることが明らかになっている. また, 水みちが形成される際の流量 (以下水みち形成流 量) の通水継続時間も水みちを形成する上で重要であ ることも明らかになっている.

一方で, 流量の減水速度を考慮した場合や減水期間に おいて平水時の流量を変化させた場合などは水みちの 形成に与える影響が不明である. このため, 図-2に示す ように, 流量の減水速度が一定の場合と異なる場合, さ らに平水時の流量を変化させた場合で水みち形成にど う影響を与えるかを把握するために減水期間を 40 分と 固定し上記のようなハイドロを設定することとした.

\section{3. 水理実験概要}

\section{(1) 実験方法および条件}

実験に用いる水路は, 図-3 に示すような, 長さ $8 \mathrm{~m}$, 幅 $0.3 \mathrm{~m}$ の直線水路である. 移動床実験に用いた河床材料 は, 益本ら ${ }^{8)}$ らの研究と同樣に,4 号硅砂 $\left(d_{m}=0.765 \mathrm{~mm}\right)$ と 7 号硅砂 $\left(d_{m}=0.154 \mathrm{~mm}\right)$ を $5: 1$ に配合した混合砂で ある. この河床材料を水路に敷きつめ, 河床勾配 $1 / 80$ の 初期河床を形成した.

実験は, 洪水減水期のハイドロ形状が, 十分に発達し た交互砂州地形における水みち形成に与える影響を調 べるため, 次の二段階で行った. 図-4 に実験フローを示 す. 第一段階は, 洪水期に形成される交互砂州を形成さ せるため, 十分発達した交互砂州が形成される流量 (以 (a)
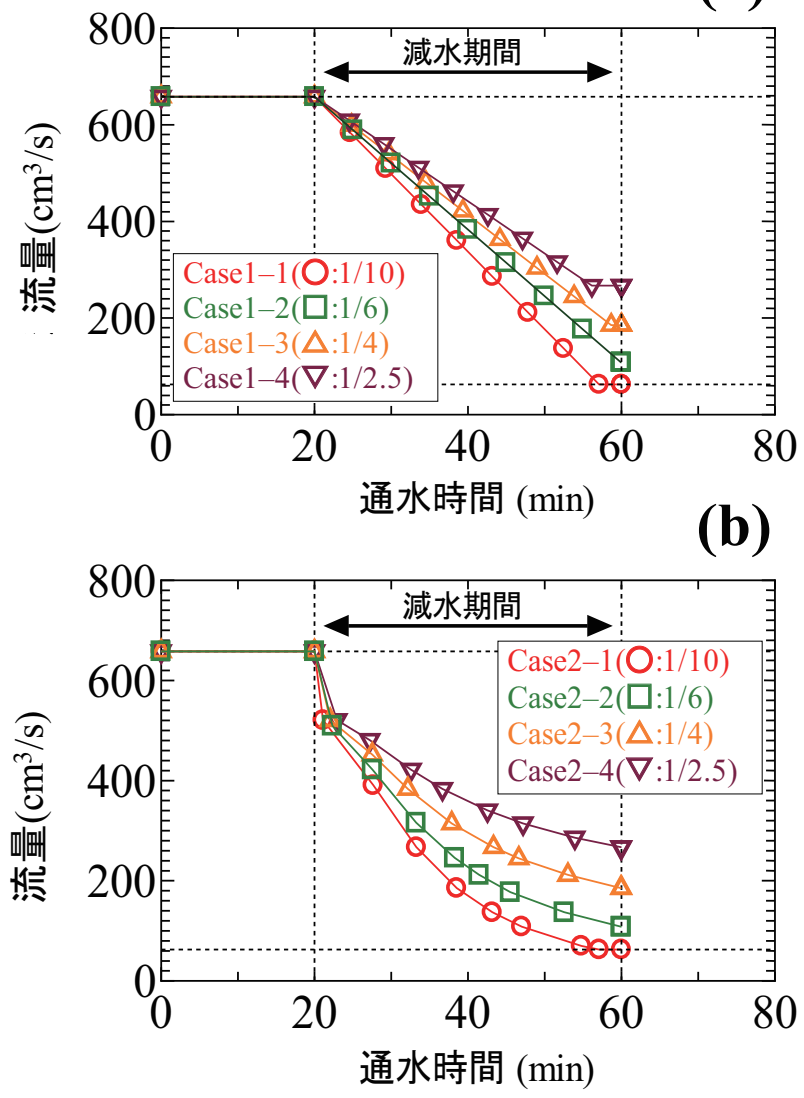

図-2 時間的に減水速度と減水比が異なるハイドログラフ

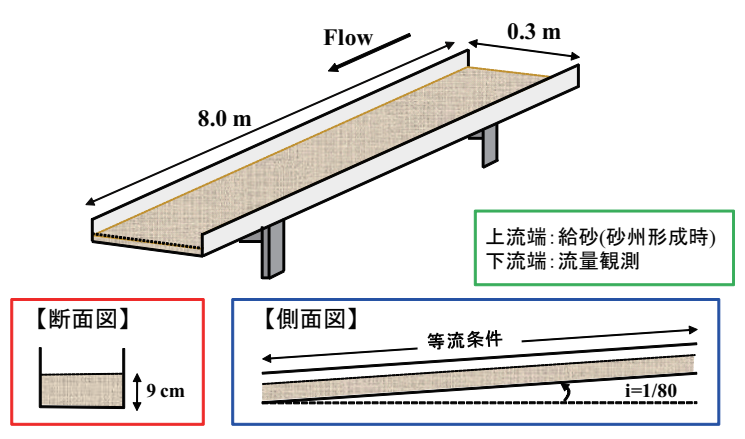

図-3 実験水路の模式図

表-1 水路実験における減水方法と減水比

\begin{tabular}{|c|c|c|}
\hline 通水ケース & 減水方法 & 減水比 (小流量/大流量) \\
\hline \hline Case1-1 & 直線 & $1 / 10$ \\
\hline Case1-2 & 直線 & $1 / 6$ \\
\hline Case1-3 & 直線 & $1 / 4$ \\
\hline Case1-4 & 直線 & $1 / 2.5$ \\
\hline Case2-1 & 凹型 & $1 / 10$ \\
\hline Case2-2 & 凹型 & $1 / 6$ \\
\hline Case2-3 & 凹型 & $1 / 4$ \\
\hline Case2-4 & 凹型 & $1 / 2.5$ \\
\hline
\end{tabular}




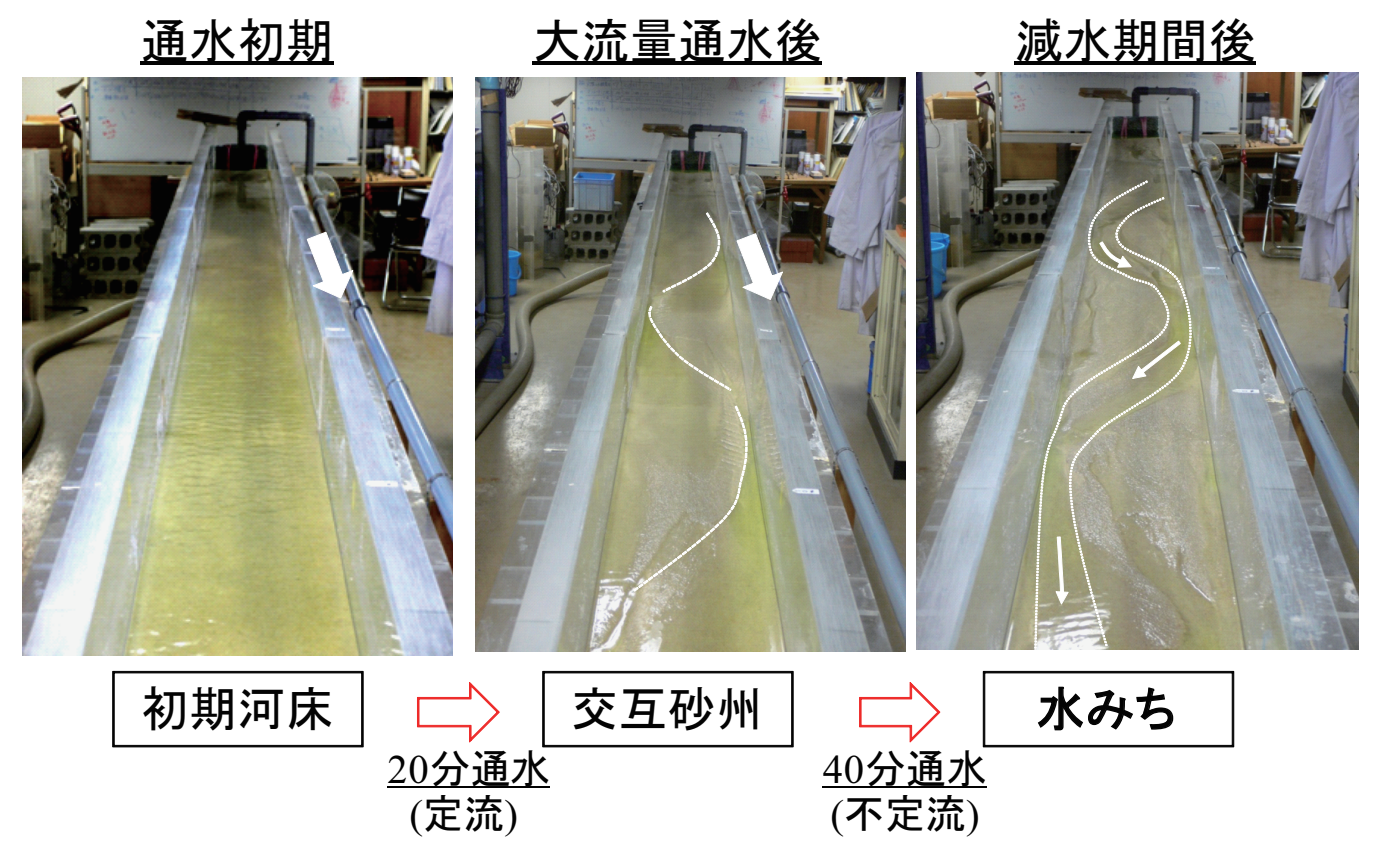

図-4 実験フロー

下大流量と呼ぶこととする）を一定時間, 定流で通水す る. 第二段階は, 第一段階で形成した交互砂州を初期河 床として, 流量を後述するハイドロ形状で咸少させてい き, 水みちを形成させる. また本実験の初期水理条件 (大 流量) は, 交互砂州からの水みち形成要因を調べるため, 交互砂州が形成されるように, 渡邊ら ${ }^{9)}$ か定常流実験で 用いた川幅水深比と中規模河床形態の関係を参考にし決 定した. なお，上流の河床低下を抑制し流砂の動的平衡 状態とするために, 大流量時のみ乾燥砂を上流端から常 時供給した. 実験に用いたハイドロ形状は, 図-2(a),(b), 表-1 に示すように, 減水期間を 40 分と固定し, 減水速 度を時間的に一定にした場合 Case1 と減水速度が時間 的に異なる場合 Case2 の実験を行った. また実験では, 水みち形成への流量の秛減勾配 (以下減水速度とする) の影響を把握するため, 平水時の流量と洪水時の流量 が異なる場合として,Case1においては小流量が大流量 の 1/10(Case1-1),1/6(Case1-2),1/4(Case1-3),1/2.5(Case14) とした条件と Case2 においては, 小流量が大流量 の 1/10(Case2-1),1/6(Case2-2),1/4(Case2-3),1/2.5(Case24)とした条件で実験を行った.

\section{(2) 測定項目}

実験での測定項目は, 河床高, 流量, 浮き州形成時刻お よび光の位置, 流水幅 (以下水みち幅) である. 水みち幅 は、減水期間にバルブ操作を行う前に, 目視で最もよく 水みち形成している幅をスケールで直接 3 力所測定し, 平均したものを水みち幅とした。河床高の測定は図-5 に示すように, 実験の各段階で, 交互砂州一対の河床を 基準に, 砂州の移動を考慮した予備区間を設けて, 縦断 方向に $10 \mathrm{~cm}$, 横断方向に $1 \mathrm{~cm}$ 間隔で砂面計を用いて測 定した. 流量観測は, 流量が想定したハイドロ形状を満
(正面図)

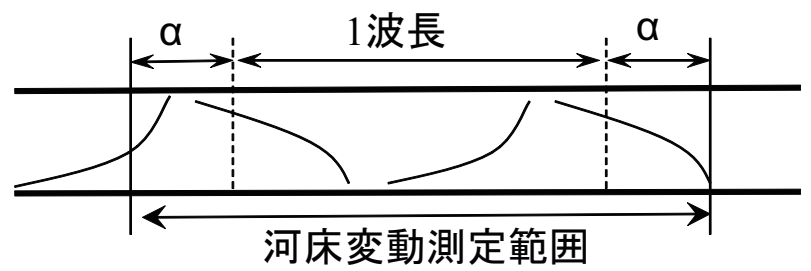

測定間隔:縦断、横断方向に $10 \mathrm{~cm} 、 1 \mathrm{~cm}$ 予備区間 $\alpha: 50 \mathrm{~cm}$

図-5 河床高測定区間

たしているかを確認するため, 流量バルブを操作する度 に行った.バルブ操作のタイミングは, 上流端の給水タ ンクにおける貯留効果を考慮して決定した. 浮き州形成 時刻および場所は,水みちが形成される契機となるため, 通水開始から浮き州形成までの時間と発生位置を把握 することとした.

\section{4. 実験結果および考察}

(1) ハイドロの減水速度の比較

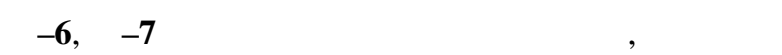
と流量の関係を示す. 無次元掃流力の算出方法を以下に 示す.

$$
\tau *=\frac{h i}{s d}
$$

無次元掃流力 $\tau *$, 水深 $h$, 河床材料の水中比重 $s$, 河床材 料の粒径 $d$, 縦断的平均河床勾配 $i$ である. なお,(a)〜 
(d) は減水速度が一定の Case1 の実験結果であり,(e)〜 (h) は凹型ハイドロの Case2 の実験結果である. 図-6の (a),(b),(c),(d) の結果から減水速度が一定の場合では, 減 水比に影響することなく,(a) を除いて概ね先行の実験結 果と同樣に流量減少過程で掃流力か増加した. また, 最 も減水勾配の大きいCase1-1である (a) の結果では, 水み ち形成の現象か明瞭に表れなかったのに対し,(c) および (d) の緩やかな減水勾配である Case1-3 および Case1-4 では減水期後半にかけて無次元掃流力か増加し, 水みち 形成の現象が明瞭に表れているように見える.しかしな がら, 目視観察では砂州を発達させるような洪水減水期 前半の大流量が長期化した影響で, 十分に発達した交互 砂州の両岸に形成される深掘れが進行・拡大しながら 流水によって, 水みちが形成されたため, この現象によ り水みち形成流量に達する前に, 十分に発達していない 水みちが形成された.つまり, 水みち形成流量に達する 前に,さほど側方への浸食を伴っていない水みちが形成 されたものであると考えられる. また,(c),(d)では水みち が活発に形成される前に通水を終了したため, 兴の後の 水みち変遷過程を把握できなかった.

以上をまとめると, 減水速度が一定の場合では, 水み ち形成流量に達しかつ Case1-1 に比較し減水勾配の緩 いCase1-2 が最も明瞭に水みち形状を呈した.

一方で, 図-6(e),(f),(g),(h) の結果から, 減水速度か時間 的に異なる場合 (減水方法: 凹型) においても, 減水比に 影響することなく, 流量減少過程で概ね掃流力か増大し た. また, 減水勾配が相対的に急でかつ水みち形成流量 に達した Case2-1やCase2-2 である (e),(f) では, 水みち 形成の現象が明瞭に呈したのに対し, 緩勾配の Case2-3 およびCase2-4の (g),(h) の結果では, 減水方法が直線型 の Case1-1(a),Case1-3(c),Case1-4(d) と同樣に, 現象が明 瞭に表れなかった.この原因として, 減水において水み ちを形成させるような流量に達していなかったことが 考えられる. 以上の結果より, 水みちが明瞭に形成され るためには, 流量が水みち形成流量になる過程が必要で ある.

次に水みち幅に着目する. 図-7でのCase1 の結果を示 す (a),(b) から, 減水速度か時間的に一定の場合では, 減 水比か変化しても通水終了前の最終的な水みち幅は光 れ光れ $8 \mathrm{~cm}, 10 \mathrm{~cm}$ と $8 \sim 10 \mathrm{~cm}$ に収束している. また減水 勾配が比較的大きい Case1-2 では, 水みち形成流量 (約 $190 \mathrm{~cm}(3 / \mathrm{s}))$ で形成された水みち幅が若干縮小変化して いるものの平水時の流量まて濰持されている.すなわち, 水みち形成流量よりも小さな流量になると, 側方への浸 食がなくなり, 水位のみ低下して水みちの形状は光のま ま維持されるため, 水みち形成流量通水時に最終的な水 みち幅が決定されている. 対称的に, より緩勾配の実験 である Case1-3(c) およびCase1-4(d) では,Case1-1 およ びCase1-2 の現象とは異なり, 通水中水みち幅か㴼小変 化し続けている.

一方, 図-7での Case2 の実験結果を示す (e),(f),(g),(h) から, 減水速度が時間的に異なる場合では, 減水比
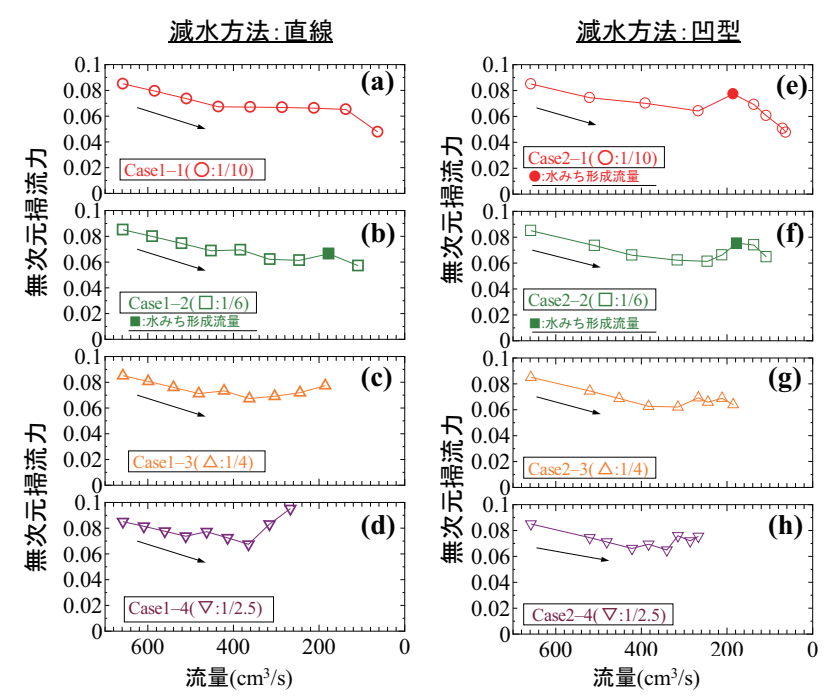

図-6 減水速度が一定の場合と異なる場合における無次元掃流 力と流量の関係
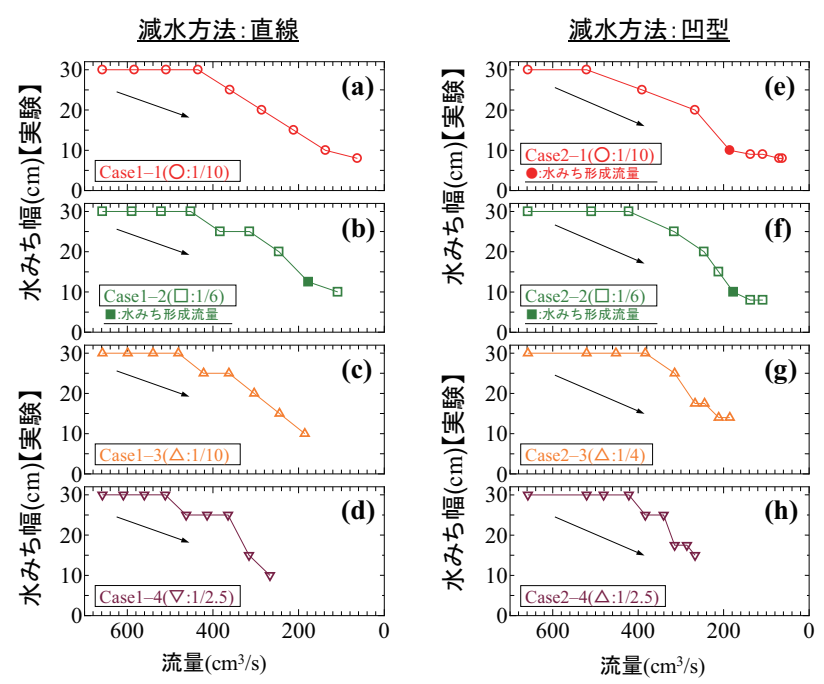

図-7 減水速度が一定の場合と異なる場合における水みち幅と 流量の関係

が大きくなるにつれ, 最終的な水みち幅が弚れ艺れ $8 \mathrm{~cm}, 8 \mathrm{~cm}, 15 \mathrm{~cm}, 15 \mathrm{~cm}$ と特定の水みち幅に収束せず大き くなる傾向がある. 減水勾配が大きい Case2-1 および Case2-2 では,Case1-2 と (b) の結果と同樣に, 水みち形 成流量で形成された水みち幅が流量逢減に伴っても縮 小変化せず,最終的な水みち幅が決定されている. 対称 的に, 減水勾配の緩い Case2-3 および Case2-4 は水みち 幅が流量の減少とともに時間的に縮小傾向を呈してい るものの (a),(b) に比較して, 明瞭な水みちが形成され なかった. この理由としては, 前述のとおり水みち形成 流量まで達しない流量設定であったためと考えられる.

次に水みち形成流量や減水速度の影響による水みち 形成の違いを詳しく調べるために, 最も水みちの形状が 明瞭であった Case2-2 の水みち形成流量 (約 $190 \mathrm{~cm}\left({ }^{3} / \mathrm{s}\right)$ ) と減水速度で, 全ての通水ケースの流量と減水速度を光 


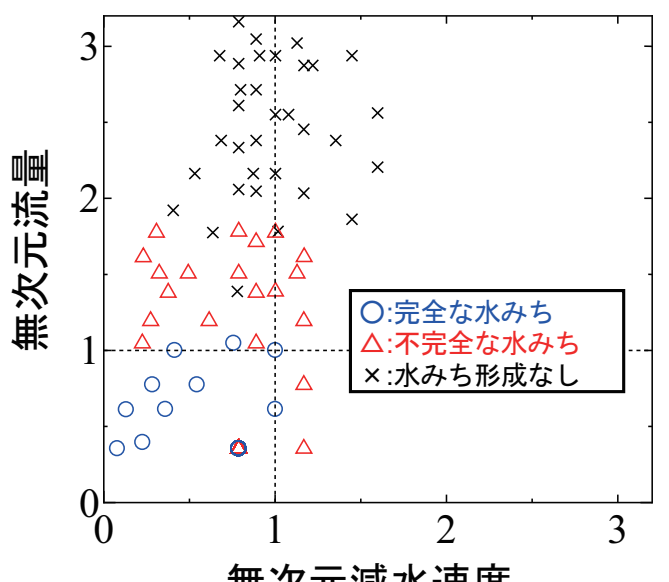

無次元減水速度

図-8 無次元流量と無次元速度の関係

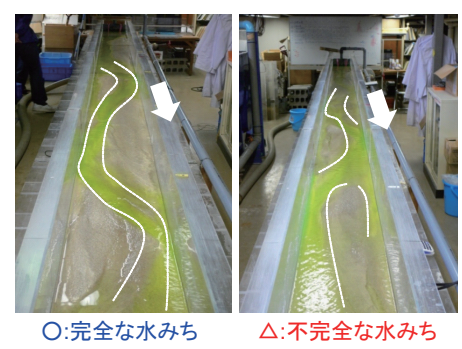

図-9 水みち形状での判定判例 $(\bigcirc:$ 完全な水みち、 $\triangle$ : 不完 全な水みち)

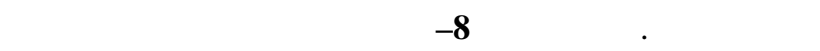
瞭に形成されている状態を○とし, 水みちが一本に収束 せずに分岐する場合や, 河床の明瞭な浸食を伴わず表面 流のみが一筋の流水となった場合等不完全な水みちを $\triangle$ とし, 水みち状のものが全く形成されていない場合を $\times$ とした. 図-9 に水みち形状の判定の一例を示す. 図-8 より, 無次元流量と無次元速度がともに 1 以下である場 合に, 水みちが形成されたと判断される結果となった. すなわち, 減水後期の減水勾配が緩い場合でかつ減水過 程で水みち形成流量を経験する場合にのみ明瞭な水み ちが形成されることを示している.以上の実験結果より, 水みちの形成要因には, 減水後期の流量と減水勾配が重 要な要素であると考えられる. また, 流量の減少に伴い, 流水が砂州前縁部を横切る際に段落ち状の局所的な射 流となり,ヘッドカット現象が生じる. 明確な水みち形 成には, この現象がある程度継続する必要があることか ら, 減水期にこの流れの状態が生じる流量と炎の継続時 間が重要な要素となる.

\section{(2) 実験での水みち幅と理論的な川幅の関係}

礫床河川の川幅と水理量との関係は, 池田 ${ }^{12)}$ によっ て,式(1)で表されている.ここでは, 実験で得られた水 みち幅と水理量との関係を把握するために, 式 (1)にお ける川幅を水みち幅として検討することとした.すなわ ち, 与えられた水理量で式 (1) から求められた川幅を理

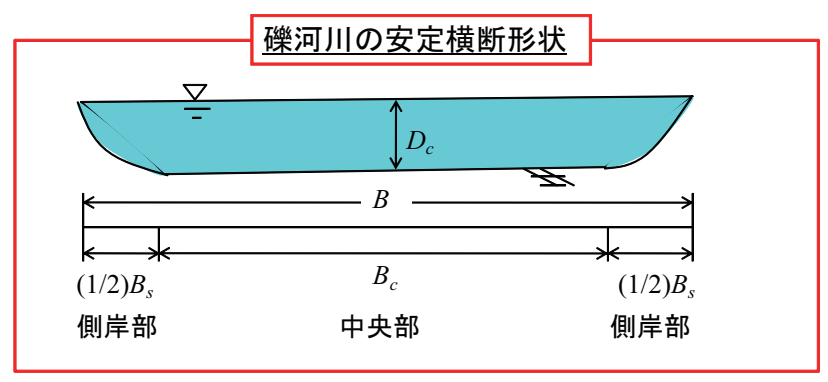

図-10 磁床河川の安定横断形状模式図
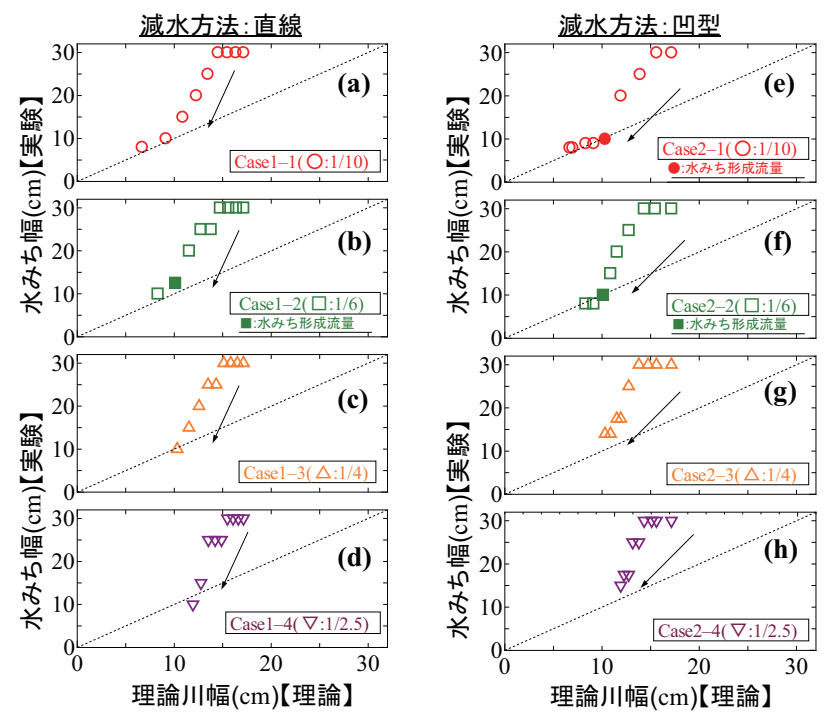

図-11 実験で得られた水みち幅と理論的な川幅の関係

論川幅とし, 実験で得られた水みち幅との比較を行った. ここで, 式 (1) は河岸の流砂の安定から導かれたもの であり, 川幅の拡幅を前提としており, 本論文で扱って いる流量が減少していく現象には、適用できないもの と判断される. しかしながら, 今回の実験では水みちの 形成過程においては, 流量が減少中においても, 水みち 形成が活発な時点では、水みち中央部の流砂が活発で あり水みち両側岸部が浸食しながら水みちが明瞭化す る傾向がみられたため, 本実験結果と池田の理論とを比 較することとした.

$$
B=\frac{Q}{D_{c} \sqrt{g D_{c} I} 2.5 \ln \left(11 \frac{D_{c}}{k_{s}}\right)}+\left[2.57+\frac{2.07}{\ln \left(11 \frac{D_{c}}{k_{s}}\right)}\right] D_{c}
$$

理論川幅 $B$, 粒径 $k_{s}$, 重力加速度 $g$, 流量 $Q$, 河床勾配 $I$, 水路中央部における水深 $D_{c}$ である.

また, 河床材料と河床抵抗の関係には,Engelund \& Hansen の式を適用した. なお理論川幅は流量, 粒径, 河 床勾配, 川幅中央の水深のみで決定される. 図-10, 図-11 に, 兴れ光れ安定横断形状の模式図と実験で得られた水 みち幅と理論式で得られた川幅の関係を示す.

減水速度か時間的に一定の場合, 減水比に関係なく減 水が進行するにつれて形成された水みち幅が, 池田の理 

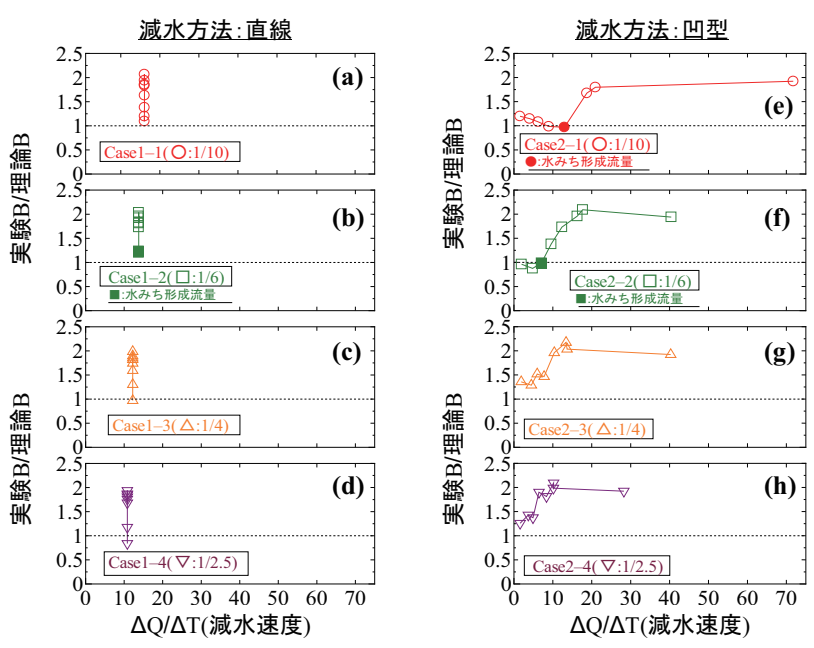

図-12 実験 $\mathrm{B} /$ 理論 $\mathrm{B}$ と $\Delta \mathrm{Q} / \Delta \mathrm{T}$ (減水速度) の関係

論川幅に収束していることがわかる. また最終的な水み ち幅も, 理論川幅に収束していることがわかる. 減水速度 か時間的に異なる場合においても,Case2-1,Case2-2にお いては, 水みち形成流量で形成された水みち幅も最終的 な水みち幅も理論川幅に収束した. しかしながら,Case23,Case2-4 においては理論川幅に完全に収束しなかった. この理由として, 前述したように Case2-3,Case2-4に関 しては, 水みちの形成現象が水みち形成流量に達するこ となく, 通水が終了したために, 水みちが十分に形成さ れることなく,縮小変化しなかったものであると考えら れる.

図-12に, 実験で得られた水みち幅を池田の理論川幅 で無次元化したものと, 減水速度 $(\Delta \mathrm{Q} / \Delta \mathrm{T})$ との関係 を示す. 図-12 より, 減水速度に依存することなく, 水み ち形成時の流量では, 水みち上での流砂が活発化し, 水 みちの拡幅現象が一時的に生じるため, 水路実験で得ら れた水みち幅は池田の安定横断形状を適用した理論川 幅に収束するものであると考えられる. 水路実験におい て水みち形成流量で形成された水みち幅は池田の安定 横断形状を適用した理論川幅と比較すると, 今回の実験 で再現可能であることが明らかとなった。

\section{5.おわりに}

本研究の結論は, 以下の通りである.

- 水みち形成要因として, 洪水減水後期の流量と減水 速度が重要であることが明らかとなった。

・池田の理論川幅と実験で得られた水みち幅を比較
すると,水みち形成流量で形成される水みち幅と最 終的な水みち幅は,理論川幅を用いることによって 推定可能となった.

洪水時の水理量の時間変化に伴う砂州の形状変化や 洪水時に形成された砂州と平水時に形成される水みち との関係において, 本研究では洪水時に形成される砂州 と平水時に存在する水みちとの因果関係を明らかにす ることを試みた. 乥の結果, ハイド口の減水勾配 (減水速 度) や減水比が, 水みち形成に影響していることを明ら かにした. 今回の結果とこれらの課題は, 将来の河川・河 道管理に対して, 治水安全度や自然生態系保全の観点よ り,重要な指標としての位置づけになりうるものである と考えられる.

謝辞: 本研究は, 科学研究費補助金基盤研究 (B)(代表:渡 邊康玄、課題番号:20360224)の助成を受けて行われた. 記して謝意を表す。

\section{参考文献}

1) 土木学会水理委員会「洪水流の三次元流況と流路形態に 関する研究」(研究代表者: 芦田和男) 土木学会論文集 第 345 号,pp41-52,1984.

2) 清水康行; 沖積河川における流れと河床変動の予測手法に 関する研究, 開発土木研究所報告 第 93 号,pp1-197,1991.

3) 知花武佳, 佐々木学, 辻本哲郎: 交互砂州が形成された河道 に生じる水際環境に関する研究, 応用生態工学研究会第 7 回研究発表会講演集,pp231-234,2003.

4) 三輪浩, 大同淳之, 横川純: 交互砂州における水みち形成過 程に及ぼす土砂供給と砂磁の分級の影響, 土木学会水工学 論文集第 49 巻,pp949-954,2005.

5) 寺本敦子, 辻本哲郎: 自己形成流路の形成過程と形成水理 条件, 土木学会論文集 第 667 号,pp75-86,2001.

6) 渡邊康玄, 安田浩保, 島田友典: 中規模河床波の低流量時に おける形状変化過程に関する水理実験, 土木学会水工論文 集第 51 巻,pp1039-1044,2007.

7) 工藤拓也, 渡邊康玄, 清水康行: 流量変化を伴う砂州形成後 の水みちの形成過程に関する実験, 土木学会北海道支部論 文報告集 第 64 号,pp.59-74,2008.

8) 益本孝彦, 渡邊康玄, 佐々木章允: 洪水減水期における水 みち形成に関する実験, 河川技術論文集 第 15 巻,pp225230,2009.

9) 渡邊康玄, 桑村貴志: 複列砂州のモ一ド減少過程に関する水 理実験, 土木学会水工学論文集 第 48 巻,pp997-1002,2004.

10) 渡邊康玄, 早川博, 清治真人: 安定解析に基づく川幅の自律 形成機構, 土木学会水工学論文集 第 53 巻,pp739-744,2009.

11) 渡邊康玄, 佐藤耕治, 大山史晃: 非定常流の下での砂州形 成実験, 土木学会水工学論文集 第 46 巻,pp725-730,2002.

12) 池田駿介: 詳述 水理学, 技報堂出版,pp400-405,1999.

( 2010.9.30 受付) 